\title{
Expression of parathyroid hormone-related protein (PTHrP) and the PTH/PTHrP receptor in the rat uterus during early pregnancy and following artificial deciduoma induction
}

\author{
J. Tucci and F. Beck \\ Howard Florey Institute of Experimental Physiology and Medicine, University of Melboume, \\ Parkville 3052, Victoria, Australia
}

\begin{abstract}
The interaction between parathyroid hormone-related protein (PTHrP) and the parathyroid hormone $(\mathrm{PTH}) / \mathrm{PTHrP}$ receptor is thought to play a role in the growth and differentiation of various tissues throughout fetal development in the rodent. The aim of the present study was to define the patterns of expression of $\mathrm{PTHrP}$ and of the PTH/PTHrP receptor in the rat uterus during the early stages of normal pregnancy, and following artificial induction of a decidual reaction. Using hybridization histochemistry, we have shown that the receptor gene is switched on early in pregnancy (by 1.5 days post coitum) in the endometrial stromal cells that surround the lumen. These cells include the anti-mesometrial subepithelial stromal cells that are destined to become decidualized. This pattern continues until 5.0 days post coitum, when PTHrP is switched on in antimesometrial luminal epithelial cells that line the implantation chamber. Stromal cells underlying the implantation chamber then downregulate transcription of the receptor gene, and within $12 \mathrm{~h}$ differentiate into decidual cells. A similar pattern was seen in uteri in which a decidual reaction had been induced artificially. Therefore, it may be postulated that in early pregnancy the endometrial stroma initiates transcription of the gene for the PTH/PTHrP receptor and is thus 'primed' for the PTHrP signal from the luminal epithelial cells. Some time after receiving the signal, the endometrial stromal cells downregulate the receptor gene, and this appears to be a trigger for the terminal differentiation of the stromal cells into decidual cells. These results suggest that $\mathrm{PTHrP}$, acting through the PTH/PTHrP receptor, plays a role in the initiation of a decidual reaction during early pregnancy by regulating the differentiation of endometrial stromal cells into decidual cells.
\end{abstract}

\section{Introduction}

Parathyroid hormone-related protein $(\mathrm{PTHrP})$ shares homology in the first 34 amino acids with parathyroid hormone (PTH), allowing it to bind to the PTH receptor (Jüppner et al., 1991) and mediate similar functions in experimental systems (Kemp et al., 1987). This receptor is able to activate both the adenyl cyclase/protein kinase $\mathrm{A}$, and the protein kinase $\mathrm{C}$ pathways (Abou-Samra et al., 1992). A different receptor for the amino terminal region of PTHrP has been suggested, which signals through either the protein kinase $\mathrm{C}$ or protein kinase $\mathrm{A}$ pathway, depending on the tissue (Philbrick et al., 1996). In addition, there is indirect evidence for at least two more specific receptors for the PTHrP gene, since a mid-molecule fragment with the sequence of amino acids 75-84 can stimulate transplacental calcium transport in sheep (Care et al., 1990), and the carboxyl-terminal osteostatin, a peptide with the sequence of amino acids 107-111, can inhibit osteoclastic bone resorption in some cell culture systems (Fenton et al., 1991). More

Received 26 March 1997 recently, the 107-139 amino acid sequence has been shown to be a potent inhibitor of bone resorption in mice (Cornish et al., 1997).

Expression of the PTH/PTHrP receptor has been described during mouse embryonic and fetal development (Karperien et al., 1994), rat fetal development (Lee et al., 1995) and in the adult rat (Urena et al., 1993). The spatial and temporal relationship between expression of the PTHrP gene and the gene for the PTH/PTHrP receptor suggests that PTHrP is signalling through the classic PTH/PTHrP receptor in a paracrine manner: PTHrP is typically expressed in the surface epithelium while its receptor is expressed in adjacent mesenchymal tissues. These observations suggest that PTHrP acts as a growth/differentiation factor during fetal developoment (Lee et al., 1995).

The interaction between PTHrP and the PTH/PTHrP receptor appears to be important in the differentiation and formation of parietal endoderm from primitive endoderm. During early development PTHrP is expressed in cells of the trophectodermal lineage while the $\mathrm{PTH} / \mathrm{PTHrP}$ receptor gene is expressed in primitive and developing parietal endodermal 

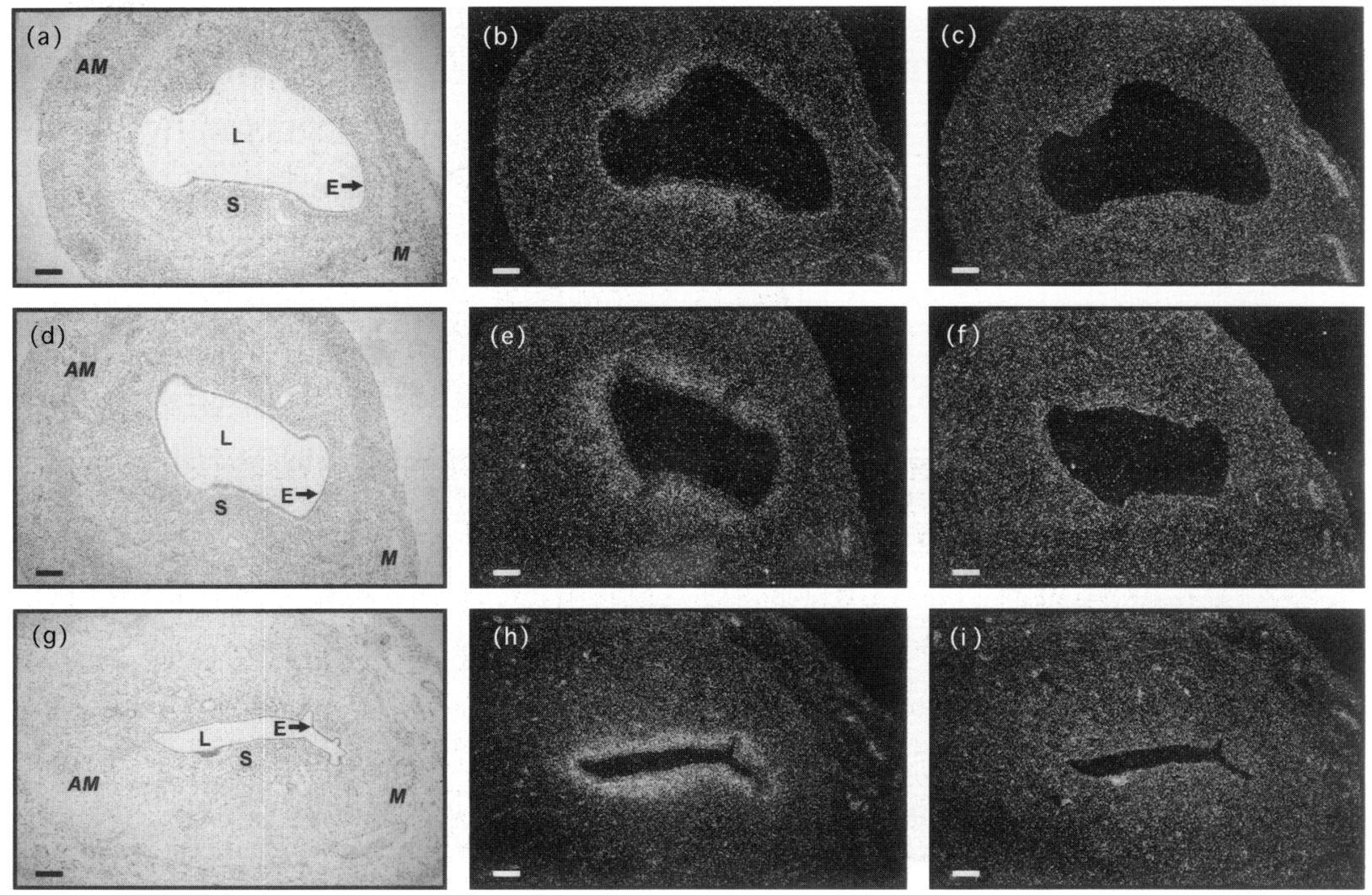

Fig. 1. In situ hybridization of anti-sense and sense cRNA probes for the parathyroid hormone (PTH) /PTH-related protein (PTHrP) receptor to adjacent sections through a rat uterus at 1.5 days post coitum $(a-c), 3.5$ days post coitum $(d-f)$ and 4.5 days post coitum (g-i). (a, $d, g)$ Brightficld micrographs of sections stained with hacmatoxylin. $A M$, anti-mesometrial pole of the uterus; $M$, mesometrial pole of the uterus; $\mathrm{E}_{\text {, luminal }}$ epithelium; L, lumen; S, endometrial stroma. $(b, c, h)$ Darkficld micrographs of sections hybridized with anti-sense probe, showing expression in endometrial stromal cells. Expression in the stromal cells appears to be upregulated between 1.5 and 4.5 days post coitum. (c. F, i) Darkfield micrographs of sections hybridized with sense probe. Scale bars represent $150 \mu \mathrm{m}$.

cells (Karperien ef $13 ., 1994)$. This observation confirms earlier in vitro studies which showed that differentiation of pluripotent embryonic stem cells into a cell type characteristic of primitive endoderm resulted in the initiation of transcription of both PTHrP and PTH/PTHrP receptor genes and the subsequent differentiation into parietal endoderm (van de Stolpe et al., 1993). Further investigation into the functional input of PTHrP during this developmental process revealed that the peptide effected a modification of the integrins on parietal endoderm cells that allow the differentiation and outgrowth of these cells on various extracellular matrix substrata (Behrendtsen et al., 1995).

Our previous studies on early rat gestation showed that at the time of implantation of the blastocyst, the gene for PTHrP was very strongly expressed by epithelial cells at implantation sites located at the anti-mesometrial pole of the uterine lumen (Beck et al., 1993). Apart from establishing the site of implantation, these epithelial cells also mark the primary decidual zone in the underlying endometrial stroma. As pregnancy progresses, the decidualized region increases in size and the invading trophectoderm (Senior et al., 1991), as well as scattered decidual cells, express the PTHrP gene. The fact that an oil-induced decidual reaction, in a pseudopregnant rat uterine horn, contained cells that transcribed the PTHrP gene indicates that uterine decidual cells are able to express PTHrP independent of input from the embryo (Beck ot al., 1993). The question arises as to the target of the PTHrP produced by the clearly defined group of epithelial cells at the anti-mesometrial pole of the lumen during implantation. Cells of the endometrial stroma and primary decidua are possible candidates, with the implication that PTHrP has a role in the rapid growth and changes in cellular morphology that characterize the uterine environment during early pregnancy, and are necessary for maintenance of the embryo. This suggestion has been strengthened by a recent series of experiments, in which the introduction of a $\mathrm{PTH} / \mathrm{PTHrP}$ receptor antagonist into the uterine lumen during the implantation period resulted in an excessive decidual response (E. D. Williams, B. J. Major, T. J. Martin, J. M. Moseley and D. D. Leaver, unpublished).

In the present study, the expression sites of PTHrP and the $\mathrm{PTH} / \mathrm{PTHrP}$ receptor during the peri-implantation period of pregnancy and in oil-induced decidual reactions in rats are described. The results obtained suggest that PTHrP is involved in regulating the onset or spread of a decidual reaction in the uterine endometrial stroma during early pregnancy and after artificial induction in a pseudopregnant uterus. It appears that the receptor gene is switched on in the endometrial stroma 

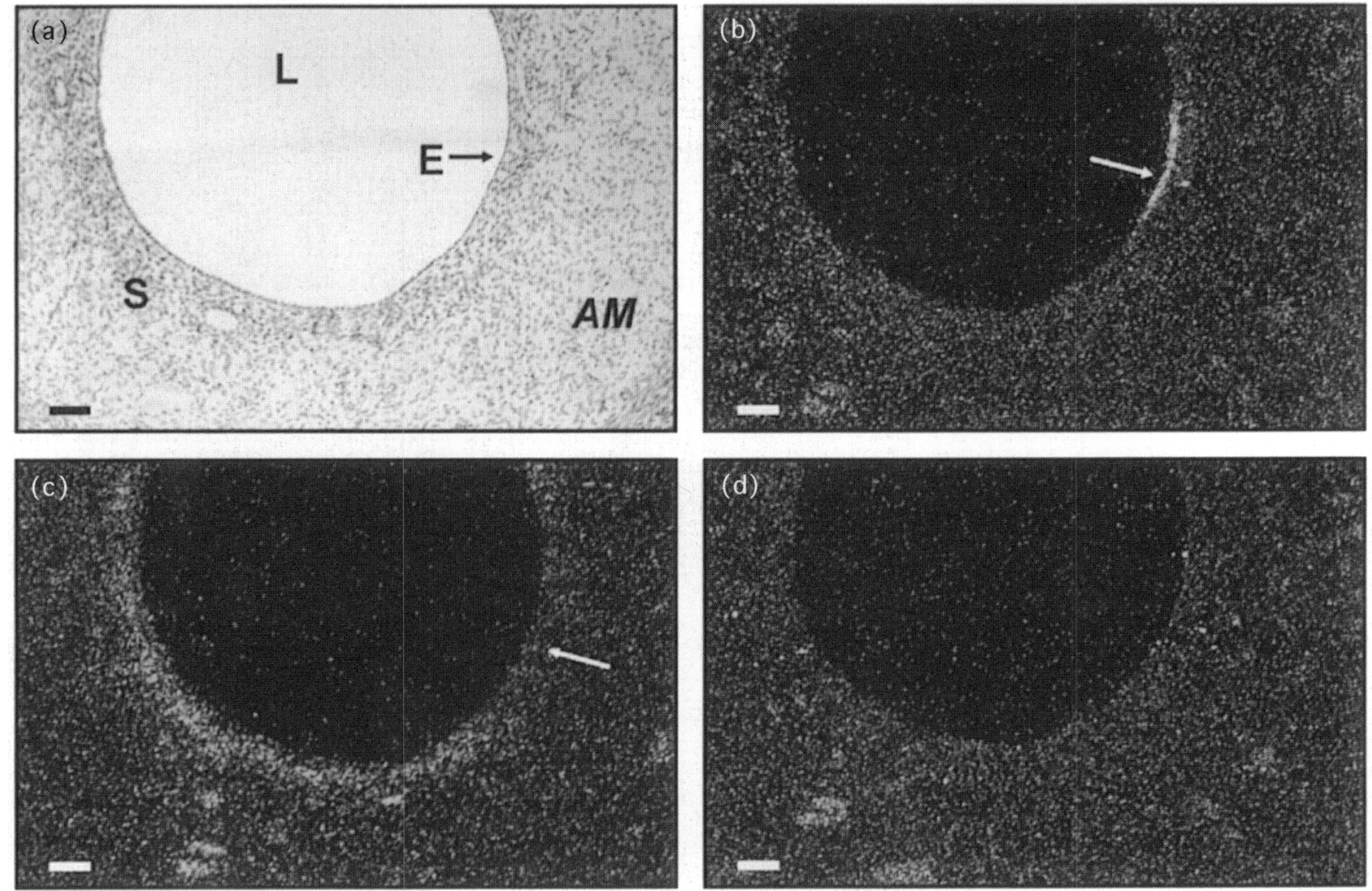

Fig. 2. In situ hybridization of cRNA probes for parathyroid hormone-related protein (PTHrP) and the PTH/PTHrP receptor to adjacent sections through a rat uterus at 5.0 days post coitum. (a) Brightficld micrograph of section stained with haematoxylin. AM, anti-mesometrial pole of the uterus; E, luminal epithelium; L, lumen; $S$, endometrial stroma. (b) Darkfield micrograph of section hybridized with PTHrP anti-sense probe, showing expression in luminal epithelial cells (arrow). (c) Darkficld micrograph of section hybridized with PTH/PTHrP receptor anti-sense probe, showing expression in stromal cells surrounding the epithelium. Expression of the receptor gene begins to be downregulated by stromal cells in the vicinity of the PTHrP-expressing epithelial cells (arrow). (d) Darkfield micrograph of section hybridized with sense probe. Scale bars represent $150 \mu \mathrm{m}$.

surrounding the lumen by 1.5 days post coitum thus 'priming' the uterus for the PTHrP message from the epithelial cells just before implantation.

\section{Materials and Methods}

Animals

Male Sprague-Dawley rats were housed individually while females were caged in groups of three or four. Animals were maintained in natural daylight and food and water were available ad libitum. A single male and female were placed in the same cage in the evening. If, on the following morning, a vaginal plug was discovered, pregnancy was timed from midnight on the evening that the male and female were caged together. Consequently, the day on which a vaginal plug was discovered was denoted as day 0.5 of pregnancy. After a lethal injection of lethobarb (Arnolds of Reading, Boronia, Victoria), uteri were collected from animals at day 1.5, 3.5, 4.5, 5.0, 5.5, and 8.5 of pregnancy. Day 5.0 of pregnancy is effectively very late in the evening of day 4.5 , which corresponds to a point midway between the times at which 4.5 and 5.5 day uteri were collected. On day 5.5 of pregnancy, deeply anaesthetized animals received an injection of a saturated solution of Evans blue dye (ICN Biochemicals, Sydney) into the aorta. Within $5 \mathrm{~min}$, sites of implantation were visible as blue dots along the length of the uterine horn. By day 8.5 of pregnancy, uterine swellings with the decidual mass and conceptus were obvious.

\section{Induction of deciduomatia}

Vasectomized males were mated with females, and if a vaginal plug was discovered, pseudopregnancy was timed as described above. On day 4.5 of pseudopregnancy, females were anaesthetized with a single i.p. injection of Nembutal (Boehringer Ingelheim, Artamon, New South Wales), at a dose of $0.1 \mathrm{ml}(100 \mathrm{~g})^{-1}$, and the left horn of the uterus tied at the extreme ovarian and cervical ends. Approximately $0.75 \mathrm{ml}$ of corn oil was then injected into the left horn between the ties, with the right horn serving as a control. Animals were killed with lethobarb $3 \mathrm{~h}, 6 \mathrm{~h}$ and $96 \mathrm{~h}$ after the injection of oil. Uteri were excised and immediately fixed in $4 \%(\mathrm{w} / \mathrm{v})$ paraformaldehyde as described below. At $96 \mathrm{~h}$ after oil 

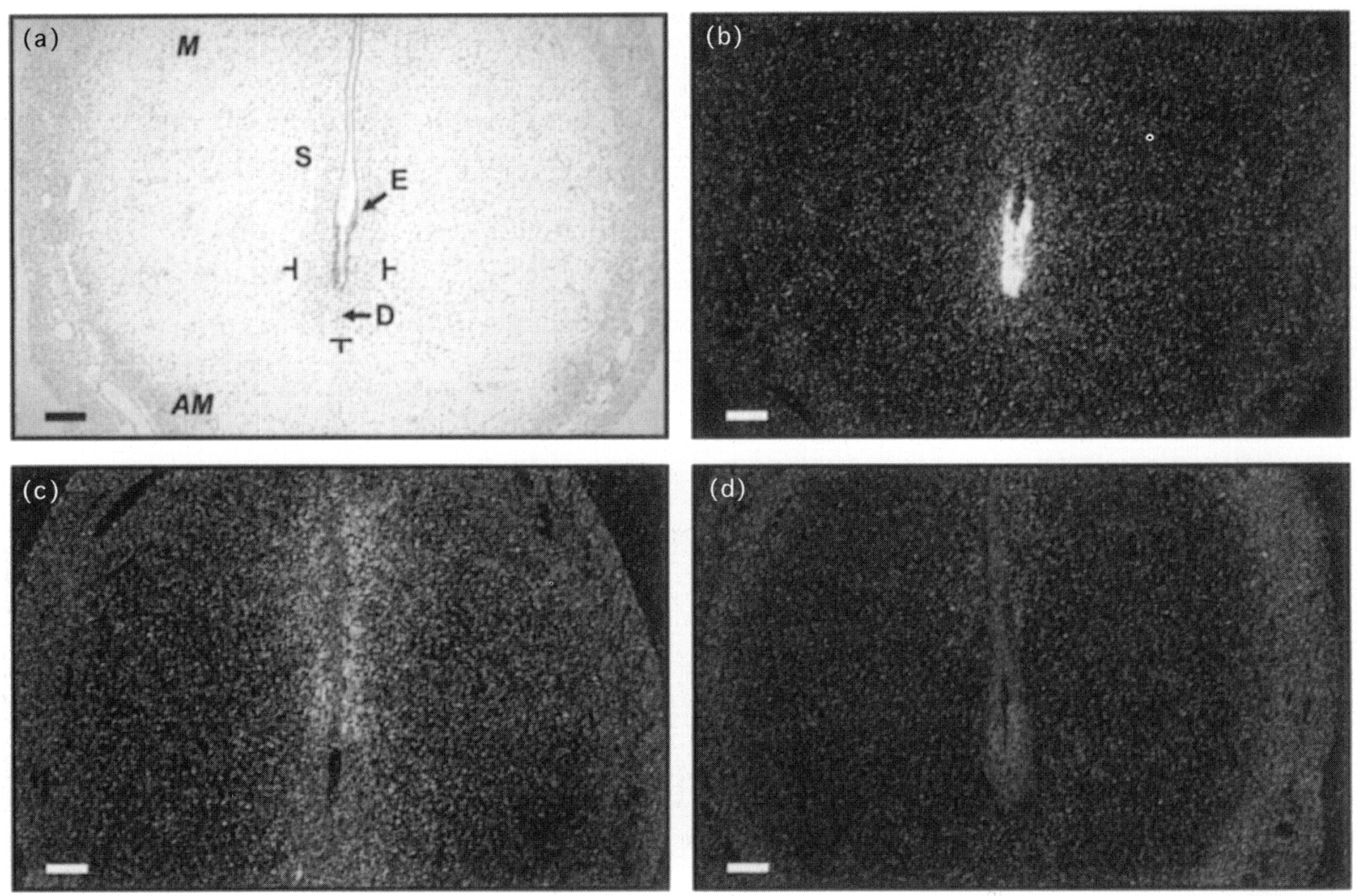

Fig. 3. In situ hybridization of CRNA probes for parathyroid hormone-related protein (PTHrP) and the PTH/PTHrP receptor to adjacent sections through implantation sites in a rat uterus at 5.5 days post coitum. These areas show the beginning of a decidual reaction. (a) Brightfield micrograph of section hybridized with PTHrP anti-sense probe and stained with haematoxylin. $A M$, anti-mesometrial pole of the uterus; $M$, mesometrial pole of the uterus; D, decidual cells; E, luminal epithelium; S, endometrial stroma; the symbols: t denote the extent of spread of decidualization. (b) Darkfield micrograph of section hybridized with PTHrP anti-sense probe, showing strong expression in epithelial cells lining the implantation chamber. (c) Darkfield micrograph of section hybridized with PTH/PTHrP receptor anti-sense probe, showing that while expression has ceased in endometrial cells that have decidualized, stromal cells that are adjacent to the lumen and have not yet decidualized continue to express the receptor. (d) Darkfield micrograph of section hybridized with sense probe. Scale bars represent $150 \mu \mathrm{m}$.

injection, a uniform uterine swelling, indicative of a decidual reaction, was visible.

\section{Detection in females of oarious stages of the oestrous cycle}

The vaginal entrance of each female was gently swabbed using a sterile cotton bud that had been moistened with sterile saline. The material was brushed onto a slide, a drop of methylene blue added, and a coverslip placed over the top. The stages of the oestrous cycle were identified according to the cellular morphology visualized by light microscopy, as described by Rugh (1968).

\section{Probes}

Transcription of cRNA probes for hybridization histochemistry is described in detail by Beck et wil. (1994). The PTHrP RNA probe is identical to that used in previous studies (Senior et al. 1991) and is transcribed from a 330 base pair rat PTHrP cDNA template coding for amino acids 34 to beyond the coding region. The rat PTH/PTHrP receptor $\mathrm{CDNA}$ sequence has been described previously by Abou-Samra et al. (1992). The cDNA sequence from nucleotides 258-1671 (a gift from $H$. Jüppner) was used as a template for probe transcription. $\left.{ }^{35} \mathrm{~S}\right]$ UTP (1500 $\mathrm{Ci} \mathrm{mmol}^{-1}$, Dupont, Sydney) was used as label for transcription of anti-sense and sense probes. Yield and quality of transcription were assessed by DE-8I paper chromatography and polyacrylamide gel electrophoresis, respectively. After transcription, probes were subjected to controlled alkaline hydrolysis and stored in $10 \mathrm{mmol}$ dithiothreitol $\mathrm{I}^{-1}$ at $-70^{\circ} \mathrm{C}$ until use.

\section{Preparation of tissue for hybridization histochemistry}

All tissues were fixed immediately in $4 \%(\mathrm{w} / \mathrm{V})$ paraformaldehyde in $0.1 \mathrm{~mol}$ phosphate buffer I $^{-1}(23 \mathrm{mmol}$ $\mathrm{NaH}_{2} \mathrm{PO}_{4} \cdot 2 \mathrm{H}_{2} \mathrm{O} \mathrm{I}{ }^{-1}$ and $77 \mathrm{mmol} \mathrm{Na} \mathrm{HPO}_{4}$ anhydrous $1^{-1}$ $\mathrm{pH} 7.2$ ). After $24 \mathrm{~h}$, samples were transferred to $0.5 \mathrm{~mol}$ sucrose $1^{-1}$ in $0.1 \mathrm{~mol}$ phosphate buffer $1^{-1}$ at $4^{\circ} \mathrm{C}$ for $24 \mathrm{~h}$ minimum before dehydrating and wax embedding. Paraffin wax sections were cut at a thickness of $5 \mu \mathrm{m}$ and mounted onto 

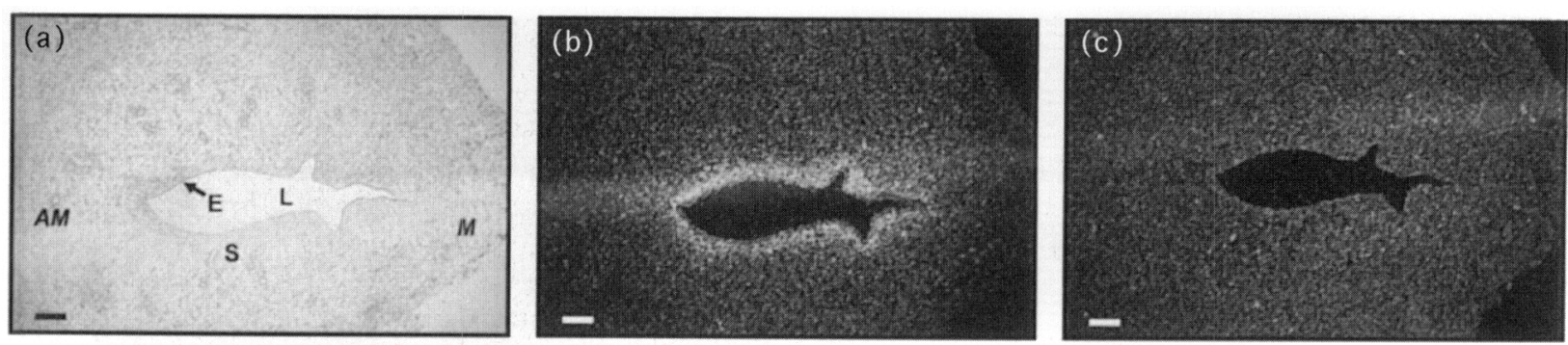

Fig. 4. In situ hybridization of anti-sense and sense cRNA probes for the parathyroid hormone (PTH)/PTH-related protein (PTHrP; receptor to adjacent sections through the rat uterus in between the sites of implantation at 5.5 days post coitum. No decidual reaction is present in these areas. (a) Brightfield micrograph of section stained with haematoxylin. $A M$, anti-mesometrial pole of the uterus; $M$, mesometrial pole of the uterus; E, luminal epithelium; L, lumen; S, endometrial stroma. (b) Darkfield micrograph of section hybridized with anti-sense probe, showing expression in all stromal cells adjacent to the lumen. (c) Darkfield micrograph of section hybridized with sense probe. Scale bars represent $150 \mu \mathrm{m}$.
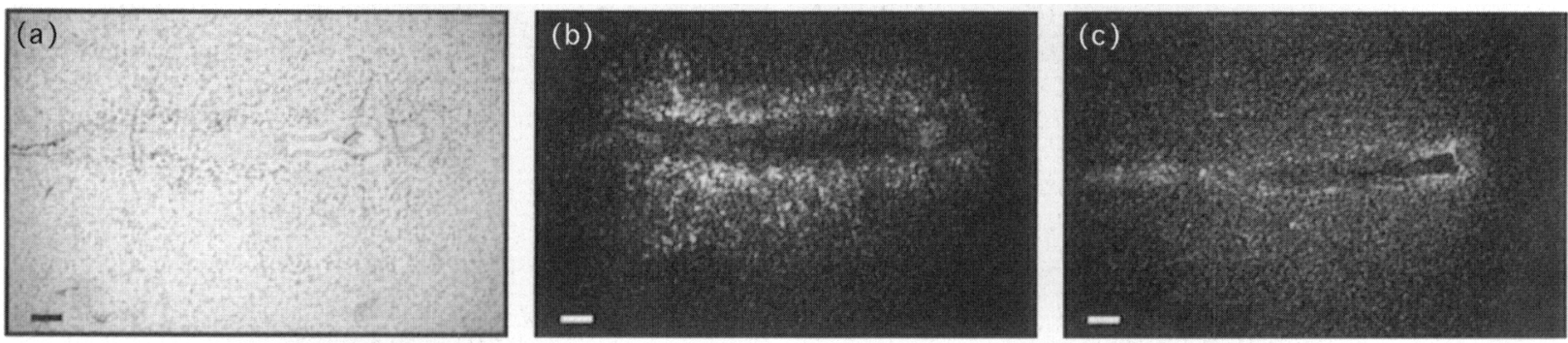

Fig. 5. In situ hybridization of anti-sense and sense cRNA probes for parathyroid hormone-related protein (PTHrP) to adjacent sections through the rat uterus at 8.5 days of pregnancy. (a) Brightfield micrograph of section stained with haematoxylin. (b) Darkfield micrograph of section hybridized with anti-sense probe, showing strong expression in some decidual and trophoblast cells surrounding the conceptus. (c) Darkfield micrograph of section hybridized with sense probe. Scale bars represent $190 \mu \mathrm{m}$.

slides that had been previously coated with aminoalkylsilane (Rentrop et al, 1986). After embedding, the uterus at day 5.0 of pregnancy was serially sectioned, and every tenth triplet of sections used for hybridization.

\section{Hybridization histochemistry}

Detailed methods regarding slide pretreatment, as well as hybridization and wash buffers and conditions are described in Beck et al. (1994). In brief, slides were dewaxed and rehydrated through a graded series of alcohols. They were then subjected to digestion with $125 \mu \mathrm{g}$ Pronase $\mathrm{E} \mathrm{ml}^{-1}$ (Sigma, St Louis, $\mathrm{MO})$ for $10 \mathrm{~min}$ and post fixed in $4 \%(\mathrm{w} / \mathrm{v})$ paraformaldehyde in $0.1 \mathrm{~mol}$ phosphate buffer $\mathrm{l}^{-1}$ for $10 \mathrm{~min}$. After this, slides were dehydrated through a graded series of alcohols and dried. The labelled cRNA probes were diluted to $50-75 \mathrm{ng} \mathrm{ml}^{-1}$ in hybridization buffer, and applied to sections. Slides were incubated at $50^{\circ} \mathrm{C}$ overnight and the following morning washed at the same temperature in three changes of a $50 \%$ formamide wash solution, followed by incubation for $2 \mathrm{~h}$ in a $150 \mu \mathrm{g} \mathrm{ml}^{-1}$ solution of RNAse A (Sigma) at $37^{\circ} \mathrm{C}$. The final wash consisted of three changes (15 min each) of $2 \times$ standard saline citrate at $65^{\circ} \mathrm{C}$. Slides were then dehydrated, dried, and exposed to X-ray film (X-OMAT AR, Eastman Kodak, Rochester, NY) for $48 \mathrm{~h}$ to determine strength of signal. All slides were then dipped in K5 liquid emulsion (Ilford, Mobberley, Cheshire) that had been diluted 1:1 (w:v) in distilled water, and exposed for 7-10 days before developing and staining with haematoxylin.

\section{Results}

\section{Expression of PTHrP and PTH/PTHrP receptor genes in} nonpregnant uteri

Sections of nonpregnant uteri at all stages of the oestrous cycle (proestrus, oestrus, metoestrus and dioestrus) were hybridized with both PTHrP and PTH/PTHrP receptor anti-sense probes. No expression of either gene was detected using the technique of hybridization histochemistry (results not shown).

\section{Expression of PTHrP and PTH/PTHrP receptor genes during normal pregnancy}

The gene for the PTH/PTHrP receptor was switched on in the uterine endometrial stroma by day 1.5 of pregnancy and continued to be upregulated until 4.5 days post coitum. At 4.5 days post coitum, all stromal cells surrounding the epithelial cells of the lumen expressed the receptor gene (Fig. 1). On day 5.0 of pregnancy, PTHrP began to be transcribed in epithelial cells at the anti-mesometrial pole of the lumen before the morphological appearance of a decidual reaction in the endometrial stroma. The gene for the receptor appeared to be slightly downregulated in the stromal cells directly adjacent to the epithelial cells expressing PTHrP (Fig. 2). These are the cells that undergo decidualization.

At 5.5 days post coitum, PTHrP was expressed in an extended number of clearly demarcated epithelial cells at the anti-mesometrial pole of the lumen (Fig. 3b). This region 

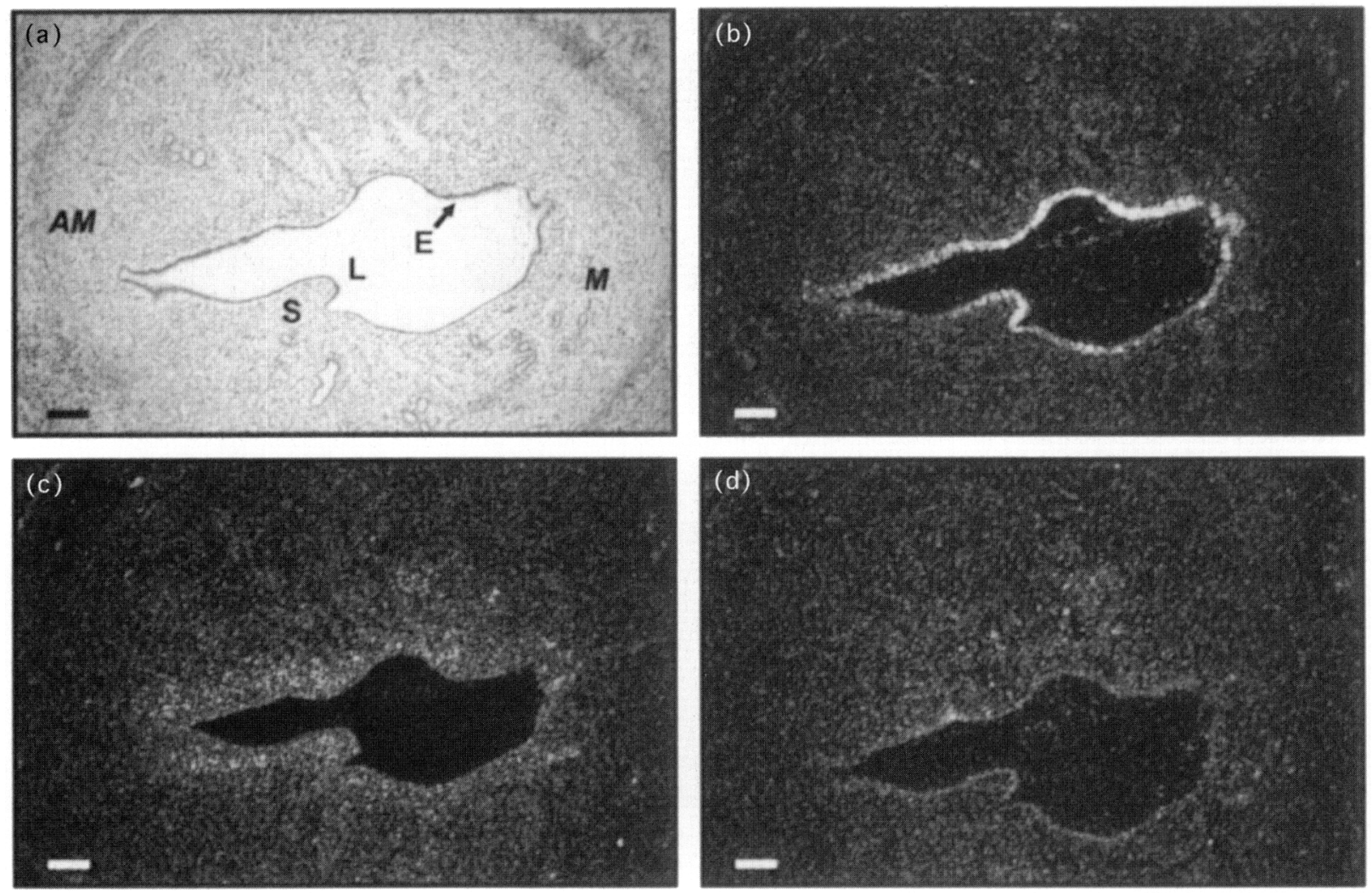

Fig. 6. In situ hybridization of cRNA probes for parathyroid hormone-related protein (PTHrP) and the PTH/PTHrP receptor to adjacent sections through the uterine horn of a pseudopregnant rat $3 \mathrm{~h}$ after an injection of oil. (a) Brightficld micrograph of a section stained with haematoxylin. $A M$, anti-mesometrial pole of the uterus; $M$, mesometrial pole of the uterus; $E$, luminal epithelium; $L$, lumen; $S$, endometrial stroma. (b) Darkfield micrograph of section hybridized with PTHrP anti-sense probe, showing expression in the epithelial cells lining the lumen. ic) Darkfield micrograph of section hybridized with PTH/PTHrP receptor anti-sense probe, showing expression in stromal cells adjacent to the lumen. (d) Darkfield micrograph of section hybridized with sense probe. Scale bars represent $150 \mu \mathrm{m}$.

denotes the site of implantation of a blastocyst, and the cells of the underlying stroma have undergone decidualization. While stromal cells surrounding the equatorial and mesometrial pole of the lumen continued to express the gene for the PTH/PTHrP receptor, the cells that had begun to decidualize had strongly downregulated the receptor gene (Fig. 3c). In sections through the uterus between implantation sites, where there is no decidual reaction, the PTH/PTHrP receptor gene was expressed at equal intensity in all stromal cells adjacent to and surrounding the lumen (Fig. 4), in a pattern identical to that seen between 1.5 and 4.5 days post coitum. PTHrP was not expressed in epithelial cells lining the uterine lumen in these regions (results not shown). At 8.5 days post coitum most of the stroma had decidualized, and expression of the PTH/PTHrP receptor gene was not detected (results not shown). PTHrP, on the other hand, was expressed by trophoblast cells and some of the decidua in close proximity to the trophoblast (Fig. 5).

\section{Expression of the PTHrP and PTH/PTHrP receptor genes in experimentally induced deciduoma}

Three hours after the injection of oil into a uterine horn at day 4.5 of pseudopregnancy, most of the epithelial cells lining the lumen of the uterus had begun to express the gene for PTHrP (Fig. 6b). Surrounding cells of the stroma still expressed the receptor gene (Fig. 6c), and at that stage, there was no evidence of a decidual reaction. Six hours after the injection, stromal cells directly adjacent to PTHrPexpressing epithelial cells began to downregulate transcription of the receptor gene (Fig. $7 b, c)$. In the same section, stromal cells, in which expression of the PTH/PTHrP receptor continued, were adjacent to epithelial cells that had not been stimulated to express PTHrP (Fig. 7b, c). There was no morphological evidence of decidualization at this stage. In non-injected control uterine horns from animals killed $3 \mathrm{~h}$ and $6 \mathrm{~h}$ after the injection of oil, the stromal cells surrounding the lumen expressed the receptor (Fig. 8). In these sections, no specific hybridization to the PTHrP probe was detected in the overlying epithelium (results not shown).

At $96 \mathrm{~h}$ after the injection of oil, the injected uterine horn was uniformly distended by a decidual reaction. Sections through this tissue revealed strong expression of PTHrP mRNA in some decidual cells close to the lumen (Fig. 9), but expression of the gene for the PTH/PTHrP receptor was not detected (results not shown). 

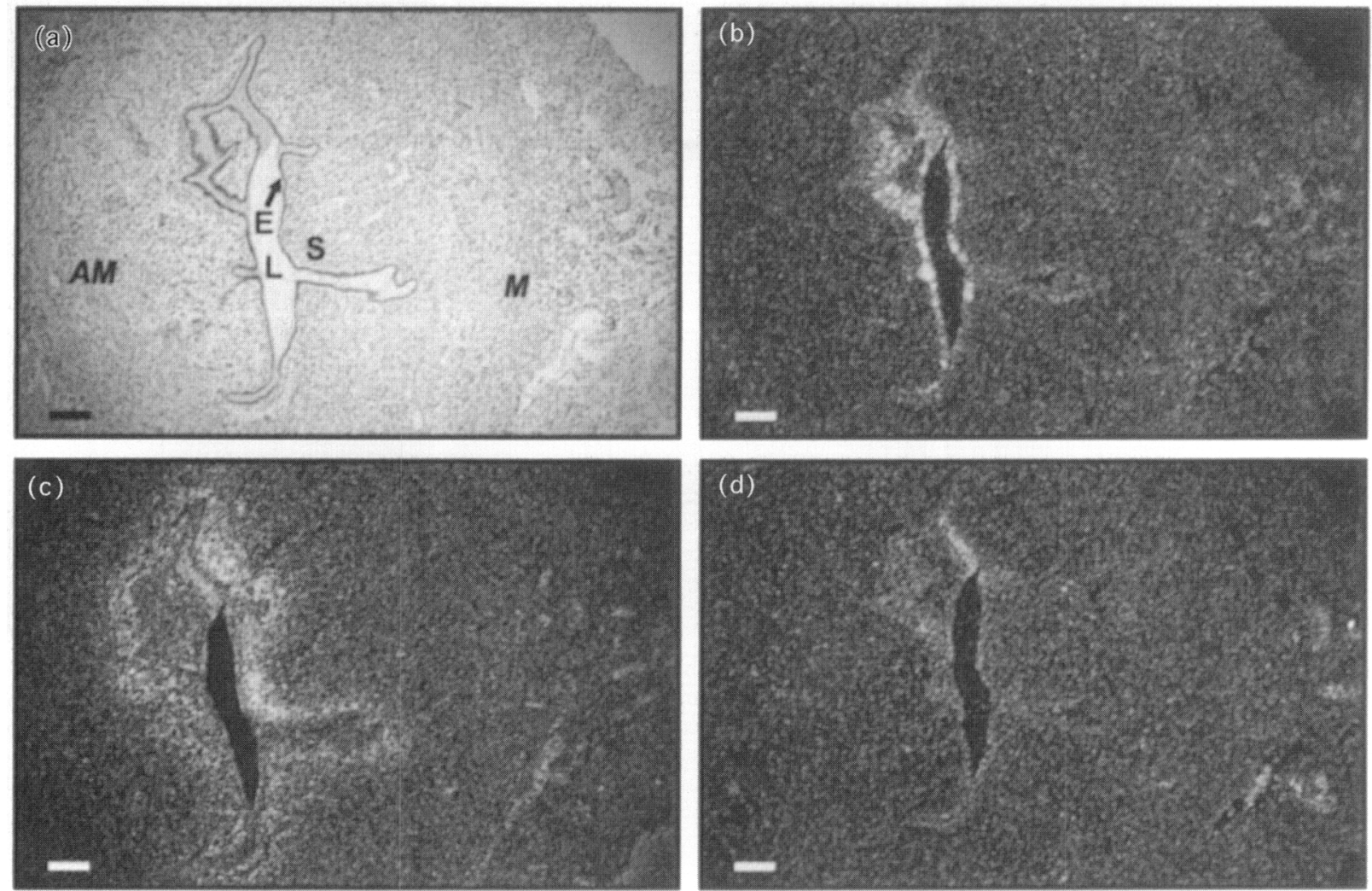

Fig. 7. In situ hybridization of anti-sense and sense cRNA probes for parathyroid hormone-related protein (PTHrP) and the PTH/PTHrP receptor to adjacent sections through the uterine horn of a pseudopregnant rat $6 \mathrm{~h}$ after an injection of oil. (a) Brightfield micrograph of a section stained with haematoxylin. AM, anti-mesometrial pole of the uterus; $M$, mesometrial pole of the uterus; E, luminal epithelium; L, lumen; $S$, endometrial stroma. (b) Darkfield micrograph of section hybridized with PTHrP anti-sense probe, showing expression in epithelial cells lining the lumen. (c) Darkfield micrograph of section hybridized with PTH/PTHrP receptor anti-sense probe, showing that some stromal cells directly adjacent to PTHrP-expressing epithelial cells have downregulated transcription of the receptor gene. In the same section, stromal cells, in which expression of the receptor gene continues, lie adjacent to epithelial cells that have not been stimulated to express PTHrP. (d) Darkfield micrograph of section hybridized with sense probe. Scale bars represent $150 \mu \mathrm{m}$.

\section{Discussion}

In rats, at day 5.0 of pregnancy, before the onset of a decidual reaction, the gene for $\mathrm{PTHrP}$ begins to be expressed in epithelial cells at the anti-mesometrial pole of the lumen. The endometrial stromal cells, that surround and are in proximity to the lumen, express the PTH/PTHrP receptor gene at equal intensity with the exception of those that are directly adjacent to the epithelial cells transcribing PTHrP; these express the receptor at lower levels, and are probably terminally committed to differentiate into decidual cells. At about the time of implantation, 5.5 days post coitum, the gene for PTHrP is very strongly expressed in the epithelial cells lining the anti-mesometrial pole of the lumen of the uterus. This site marks the crypt into which the blastocyst will implant and the underlying stromal cells, the first to become decidualized, express the gene for the PTH/PTHrP receptor at very low levels or not at all. Endometrial stroma cells surrounding the rest of the lumen at this stage are not part of the primary decidualizing zone. These cells continue to express the gene for the receptor. In areas of the uterus in between the sites of blastocyst implantation, where there is no detectable expression of the PTHrP gene, the gene for the PTH/PTHrP receptor is expressed at equal intensity in all the endometrial stroma cells surrounding the lumen. The inverse relationship between the expression of PTHrP and its receptor has been described elsewhere (Lee et al., 1995) and it has been suggested that PTHrP may downregulate the receptor gene. In the current study, expression of the PTHrP gene in the luminal epithelium at the site of implantation may provide a regulatory signal to the underlying stromal cells during their differentiation into decidual cells.

Transcription of the gene for the PTH/PTHrP receptor was not detected in nonpregnant uteri at any stage of the oestrous cycle (results not shown). Its expression is triggered after mating, thus priming the endometrial stroma surrounding the lumen of the uterus for the PTHrP signal from the epithelial cells. It is proposed that some time after the signal has been received by the endometrial stroma cells, they downregulate the receptor gene and differentiate into decidual cells.

Results obtained from expression studies of the PTHrP and PTH/PTHrP receptor genes in oil-induced deciduoma support the above suggestion. In the contralateral pseudopregnant uterine horns, that were not injected with oil, expression of the 

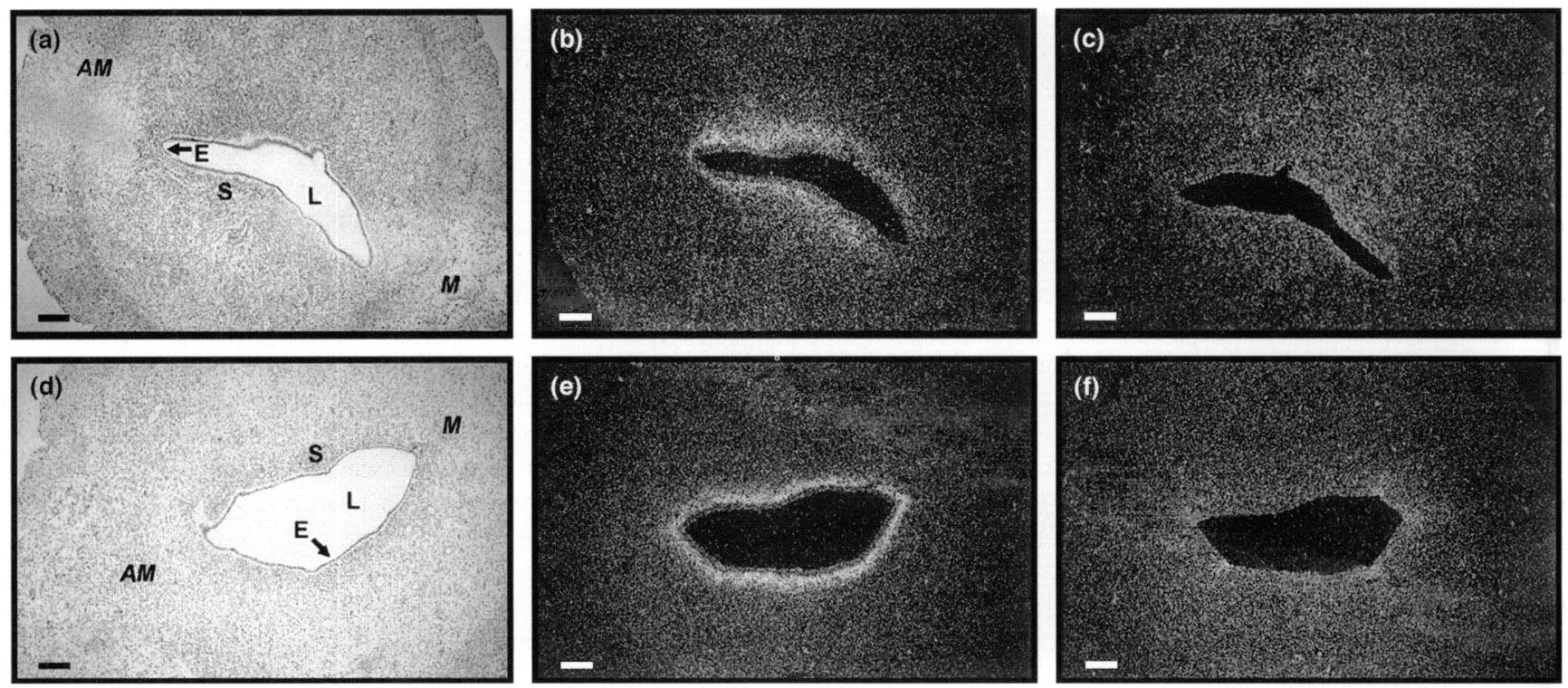

Fig. 8. In situ hybridization of anti-sense and sense cRNA probes for the parathyroid hormone (PTH)/PTH-related protein (PTHrP) receptor to adjacent sections through the non-manipulated uterine horn of a pscudopregnant rat. $(a, b, c)$ Sections through the non-manipulated horn which served as a control for sections taken from rats killed $3 \mathrm{~h}$ after the oil injection. (d, e, f) Sections through the non-manipulated horn which served as a control for sections taken from rats killed $6 \mathrm{~h}$ after the oil injection. (a, d) Brightfield micrograph of sections stained with haematoxylin. $A M$, anti-mesometrial pole of the uterus; $M$, mesometrial pole of the uterus; $E$, luminal epithelium; $L$, lumen; $S$, endometrial stroma. (b, e) Darkfield micrographs of sections hybridized with anti-sense probe, showing expression in stromal cells adjacent to the lumen. (c, f) Darkficld micrographs of sections hybridized with sense probe. Scale bars represent $150 \mu \mathrm{m}$.
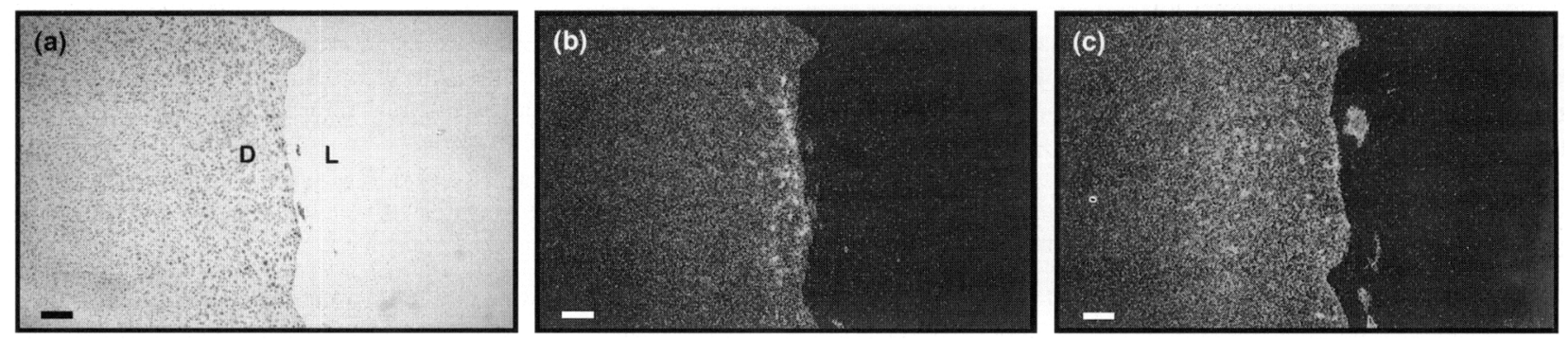

Fig. 9. In situ hybridization of anti-sense and sense cRNA probes for parathyroid hormone-related protein (PTHrP) to adjacent sections through the uterine horn of a pseudopregnant rat $90 \mathrm{~h}$ after the injection of oil. (a) Brightfield micrograph of section stained with haematoxylin. D, decidual cells; L, lumen, (b) Darkfield micrograph of section hybridized with anti-sense probe showing expression by some decidual cells close to the lumen. (c) Darkfield micrograph of section hybridized with sense probe. Scale bars represent $190 \mu \mathrm{m}$.

PTH/PTHrP receptor gene is found in the cells of the endometrial stroma that are adjacent to and surround the lumen. This finding confirms that the gene for the receptor is switched on early, possibly as a result of the secretion from the corpus luteum, and is not dependent on the embryo, or stimulation by oil.

In the oil-injected uterine horn, $3 \mathrm{~h}$ and $6 \mathrm{~h}$ after injection, the epithelial cells of the lumen strongly express the PTHrP gene. The induction by oil indicates that PTHrP transcription in the epithelial cells is triggered by mechanical stimulation or slight stretch. Expression of PTHrP within $3 \mathrm{~h}$ is in keeping with its designation as an early response gene (Philbrick ot al., 1996), which during the implantation period would be a critical factor if it were playing a role in regulating the onset of a decidual reaction. Three hours after the oil injection the receptor gene is still expressed in the stromal cells surrounding the PTHrP-expressing epithelial cells, but after $6 \mathrm{~h}$ the receptor is downregulated by PTHrP expression in the adjacent epithelial cells, although there is as yet no histological evidence of decidualization (results not shown). Ninety-six hours after the injection, (equivalent to 8.5 days post coitum) a clear decidual reaction is observed in the stroma, and decidual cells strongly expressing $\mathrm{PTHrP}$ are evident; at this stage the receptor gene is no longer expressed in the uterine endometrium. At day 8.5 of normal pregnancy, a similar result is seen, that is, strong expression of PTHrP by trophoblast and decidua, whilst in the endometrium, mRNA encoding the $\mathrm{PTH} / \mathrm{PTHrP}$ receptor is not detectable.

The temporal and spatial pattern of expression of PTHrP and the PTH/PTHrP receptor suggest a role for this peptide in regulating decidualization of the uterus during the implantation period. In a recent series of experiments, administration of a 
PTH/PTHrP receptor antagonist into the uterine lumen during early pregnancy resulted in excessive decidualization (E. D. Williams, B. J. Major, T. J. Martin, J. M. Moseley and D. D. Leaver, unpublished). These results, together with the data presented here, provide evidence for the involvement of PTHrP in decidualization, and specifically, as a negative regulator of cell differentiation.

A model for the possible sequence of molecular events involving PTHrP and the PTH/PTHrP receptor in the uterus during early pregnancy is as follows: initially, endocrine factors along with signals from the uterine luminal epithelium are likely to determine the fate of the stromal cells surrounding the anti-mesometrial pole of the lumen, the first cells to undergo decidualization. These stromal cells, as well as those surrounding the rest of the lumen, initiate expression of the receptor gene early in pregnancy. At the time of implantation, the luminal epithelial cells that line the implantation chamber are stimulated to express PTHrP, probably as a result of mechanical stimulus or contact with the blastocyst. Acting through the receptor, PTHrP inhibits premature differentiation of the underlying anti-mesometrial stromal cells which (for reasons as yet unknown) are the first to decidualize. When these cells are ready to differentiate, they downregulate expression of the receptor gene. No longer transducing the inhibitory signal, they consequently become fully differentiated into decidual cells that are then capable of stimulating nearby stromal cells to differentiate and allow the spread of the decidual reaction. PTHrP continues to be expressed by the epithelium of the implantation chamber until, with the natural progression of events, these cells are consumed by the invading trophoblast. This model proposes that PTHrP serves as a 'fine tuning' mechanism, allowing for exact timing of initiation of a decidual reaction primed to occur at the anti-mesometrial pole of the lumen. Fine tuning of further differentiation could possibly be achieved via changes in the amount of PTHrP produced by decidual cells themselves (Senior et al., 1991; Beck et al., 1993), interacting with the undifferentiated stromal cells distal to the anti-mesometrial pole that have been shown here to express the gene for the receptor.

Recent experiments studying the role of PTHrP in cartilage differentiation have demonstrated that this process is controlled by a negative feedback loop, involving PTHrP, the $\mathrm{PTH} / \mathrm{PTHrP}$ receptor, and the gene Indian hedgehog (Vortkamp et al., 1996). It is possible that an analogous sequence of events occurs in the uterus to influence the differentiation of stromal cells into decidual cells. The recent demonstration that the cell survival factor $b c l-2$ lies downstream of PTHrP in the pathway of cartilage differentiation (Amling et al., 1997) has added weight to this s'iggestion; like PTHrP, $b c l-2$ is expressed in uterine luminal epithelial cells before the onset of decidualization, and downregulated once decidualization has begun (Akcali et al., 1996).

Factors that regulate the onset of expression of PTHrP and the PTH/PTHrP receptor in the uterus require elucidation. Progesterone is a possible candidate as the trigger for initiation of PTH/PTHrP receptor gene transcription early in pregnancy, although this is still to be examined. Experiments performed in vitro have shown that transforming growth factor (TGF- $\beta$ ) and oestrogen are both able to upregulate the amounts of mRNA encoding PTHrP in cultured endometrial stromal cells
(Casey et al., 1992, 1993). While TGF $\beta$ is expressed in the decidua and embryo at a time consistent with its role as a regulator of the implantation process (Tamada et al., 1990), any role that it may play in stimulating PTHrP expression in the uterus during early pregnancy remains to be elucidated. From our studies, it appears that mechanical stimulus or contact with the blastocyst are crucial initial events in stimulating PTHrP production by the Iuminal epithelial cells.

The results presented here suggest that PTHrP has a role in the regulation of a decidual response during implantation. During this period PTHrP may induce relaxation of the myometrium (Williams et al., 1994), in addition to its role in mediating the differentiation of primitive endoderm into parietal endoderm (van de Stolpe et al., 1993). If these suggestions are correct, PTHrP appears to be a critical factor within the uterus during the initial stages of pregnancy, capable of influencing the differentiation and function of several diverse tissues.

This work was supported by the National Health and Medical Research Council. The authors thank H. Jüppner for the PTH/PTHrP receptor cDNA sequence.

\section{References}

Abou-Samra AB, Jüppner $H$, Force T, Freeman MW, Kong XF, Schipani E, Urena $P$, Richards J, Bonventre JV, Potts JT, Kronenberg HM and Segre GV (1992) Expression cloning of a common receptor for the parathyroid hormone and parathyroid hormone -related peptide from rat osteoblast-like cells: a single receptor stimulates intracellular accumulation of both cAMP and inositol triphosphates and increases intracellular free calcium Proceedings of the National Academy of Sciences of the USA 89 2732-2736

Akcali KC, Khan SA and Moulton BC (1996) Effect of decidualisation on the expression of $b a x$ and $b c l-2$ in the rat uterine endometrium Endocrinology 137 3123-3130

Amling M, Neff L, Tanaka S, Inoue D, Kuida K, Weir E, Philbrick W, Broadus AE and Baron R (1997) Bcl-2 lies downstream of parathyroid hormone-related peptide in a signaling pathway that regulates chondrocyte maturation during skeletal development Journal of Cell Biology 136 205-213

Beck F, Tucci J and Senior PV (1993) Expression of parathyroid hormone-related protein mRNA by uterine tissues and extraembryonic membranes during gestation in rats Journal of Reproduction and Fertility 99 343-352

Beck F, Tucci J and Senior PV (1994) Tissue distribution of gene expression in mammalian development. In Methods In Molecular Biology Vol. 33; In Situ Hybridisation Protocols pp 313-343 Ed. KHA Choo. Humana Press Inc., Totowa, NJ

Behrendtsen O, Alexander CM and Werb Z (1995) Cooperative interactions between extracellular matrix, integrins and parathyroid hormone-related peptide regulate parietal endoderm differentiation in mouse embryos Development 121 4137-4148

Care AD, Abbas SK, Pickard DW, Barri M, Drinkhill M, Findlay JBC, White IR and Caple IW (1990) Stimulation of ovine placental transport of calcium and magnesium by mid-molecule fragments of human parathyroid hormonerelated protein Experimental Physiology $75605-608$

Casey ML, Mibe M, Erk A and MacDonald PC (1992) Transforming growth factor- $\beta 1$ stimulation of parathyroid hormone-related protein expression in human uterine cells in culture: mRNA levels and protein secretion Journal of Clinical Endocrinology and Metabolism 74 950-952

Casey ML, Mibe M and MacDonald PC (1993) Regulation of parathyroid hormone-related protein gene expression in human endometrial stromal cells in culture Journal of Clinical Endocrinology and Metabolism 77 188-194

Cornish J, Callon KE, Nicholson GC and Reid IR (1997) Parathyroid hormonerelated protein-(107-139) inhibits bone resorption in vivo. Endocrinology 138 1299-1304

Fenton AJ, Kemp BE, Hammonds RG, Mitchelhill K, Moseley JM, Martin TJ and Nicholson GC (1991) A potent inhibitor of osteoclastic bone resorption within a highly conserved pentapeptide region of $\mathrm{PTHrP}(107-111)$ Endocrinology $1293424-3426$ 
Jüppner H, Abou-Samra AB, Freeman M, Kong XF, Schipani E, Richards J, Kolakowski LF, Hock J, Potts JT, Kronenberg HM and Segre GV (1991) A g protein-linked receptor for parathyroid hormone and parathyroid hormone related peptide Science $\mathbf{2 5 4}$ 1024-1026

Karperien M, van Dijk TB, Hoeijmakers T, Cremers F, Abou-Samra AB, Boonstra J, de Laat SW and Defize LHK (1994) Expression pattern of a parathyroid hormone/parathyroid hormone related peptide receptor mRNA in mouse postimplantation embryos indicates involvement in multiple developmental processes Mechanisms of Development $4729-42$

Kemp BE, Moseley JM, Rodda CP, Ebeling PR, Wettenhall REH, Stapleton D Diefenbach-Jagger H, Ure F, Michelangeli VP, Simmons HA, Raisz LG and Martin TJ (1987) Parathyroid hormone-related protein of malignancy: active synthetic fragments Science 238 1568-1570

Lee K, Deeds JD and Segre G (1995) Expression of parathyroid hormone-related peptide and its receptor messenger ribonucleic acids during fetal development of rats Endocrinology 136 453-463

Philbrick WM, Wysolmerski JJ, Galbraith S, Holt E, Orloff JJ, Yang KH, Vasavada RC, Weir EC, Broadus AE and Stewart AF (1996) Defining the roles of parathyroid hormone-related protein in normal physiology Physiological Reviews 76 127-173

Rentrop M, Knapp B, Winter H and Schweitzer J (1986) Aminoalkylsilane treated glass slides as support for in situ hybridisation of keratin cDNAs to frozen tissue sections under varying fixation and pretreatment conditions Histochemical Journal 18 271-276
Rugh R (1968) The Mouse: Its Reproduction and Development. Burgess Publishing Company, Minneapolis

Senior PV, Heath DA and Beck F (1991) Expression of parathyroid hormonerelated protein mRNA in the rat before birth: demonstration by hybridisation histochemistry Journal of Molecular Endocrinology 6 281-290

Tamada H, McMaster MT, Flanders KC, Andrews GK and Dey SK (1990) Cell type-specific expression of transforming growth factor- $\beta 1$ in the mouse uterus during the periimplantation period Molecular Endocrinology 4 965-972

Ureña P, Kong $X$, Abou-samra AB, Jüppner H, Kronenberg HM, Potts JT and Segre GV (1993) Parathyroid hormone (PTH)/PTH-related peptide receptor messenger ribonucleic acids are widely distributed in rat tissues Endocrinology 133 $617-623$

van de Stolpe A, Karperien M, Lowick CWGM, Jüppner H, Abou-Samra AB, Segre GV, de Laat SW and Defize LHK (1993) Parathyroid hormone-related peptide as an endogenous inducer of parietal endoderm differentiation Journal of $\mathrm{Cell}$ Biology 120 235-243

Vortkamp A, Lee K, Lanske B, Segre GV, Kronenberg HM and Tabin CJ (1996) Regulation of rate of cartilage differentiation by indian hedgehog and PTH-related protein Science 273 613-621

Williams ED, Leaver DD, Danks JA, Moseley JM and Martin TJ (1994) Effect of parathyroid hormone-related protein ( $\mathrm{PTHrP}$ ) on the contractility of the myometrium and localisation of PTHrP in the uterus of pregnant rats journal of Reproduction and Fertility 102 209-214 